\section{Dr. J. Walter Leather}

THE death of Dr. J. W. Leather on November 14 removes one of those who have been largely responsible, during the last forty years, for the development of scientific work in relation to Indian agriculture, and he cannot be allowed to pass away without some reference to his activities in this and other fields.

Born in 1860, at Rainhill in Lancashire, he entered his father's chemical factory at St. Helens after leaving school, and, when he had served an apprenticeship to chemical work there, he was sent, in 1883, to study chemistry under Kekulé at Bonn. There he stayed three years and left in 1886 with the degree of Ph.D. On leaving the University, the appointment of senior assistant to Dr. J. A. Voelcker, the consulting chemist to the Royal Agricultural Society of England, was offered to him, and he held this post for six years. During this time he developed very high technical skill in chemical work in connexion with agricultural problems, a skill which he retained throughout his career. $\mathrm{He}$ originated several new methods, and one of these-a process for the detection of castor seed in feeding-stuffs-is universally used at the present day. In 1891 he became professor of chemistry at the Harris Institute, Preston, but the call to his real life work in India came before he had really settled down there.

In 1892, as a result of the recommendations of Dr. Voelcker in his report on the improvement of Indian agriculture, the Secretary of State for India decided to appoint a chemist and an assistant chemist to the Revenue and Agricultural Department of the Government of India, and Leather was selected for the former appointment. It was in this appointment of agricultural chemist to the Government of India, and in that of Imperial agricultural chemist which followed it in 1906, that Leather did what may be considered his life work. There he remained with few intervals until 1916, when he retired and settled down in Malvern.

When Leather was appointed to India in 1892, the position he occupied led to his having to range the length and breadth of the country, studying and advising upon the various problems which were placed before him by the authorities of the various provinces. He was, in fact, the only chemist attached to all the agricultural departments in India. His activity was tremendous, but it was an almost impossible position. His publications during this period (most of which appeared in the Agricultural Ledger then edited by Dr. Watt) were varied and numerous. They include the first general account of Indian soils, the first series of analyses of Indian manures, studies of alkali and salt lands, studies of sugar-cane and the composition of the Indian varieties, and a multitude of other questions. On the whole, the conditions under which Leather worked at this time did not permit him to push any of his many inquiries to a final issue in the improvement of methods or the better utilisation of Indian resources. A summary of his work during this first stage of his Indian career is contained in his final report on the first five years of the work of the Agricultural Chemist to the Government of India, issued in 1897.

The more congenial part of Leather's Indian work came in 1904, when the Imperial Research Institute at Pusa was founded, and he settled down as the head of the chemical department at that Institute, as Imperial agricultural chemist. As a result of his activities there, we have a series of publications, most of them published as memoirs of the Department of Agriculture in India. These deal with such subjects as the water requirements of crops in India, the composition of Indian rain and dew, soil temperatures in India, the problems of drainage and the loss of water from the soil in the tropics, and the interaction of calcium carbonate and carbon dioxide in soil under tropical conditions. It cannot be said that the work he did was of an epoch-making character, but he gave us a very useful collection of data which did not exist before, and which nobody else has gathered together. Within its limits, his results were always reliable, and for several generations many workers will bless the name of Leather for the careful observations which can form the basis for real agricultural advances to be initiated by others.

So far as his work generally was concerned, Leather was essentially a laboratory worker. of his industry there was no doubt, while he had a great capacity for friendship, and there are many who look back to their association with him as a time when they were initiated into that close study of a limited objective which was the special characteristic of his work.

H. H. M.

WE regret to record the deaths on January 2, as the result of an acciderit in the Austrian Tyrol, of Mr. Kenneth F. Armstrong, aged twenty-five years, and Mr. John Howard, aged twenty-six years. Mr. Armstrong was associated with his father, Dr. E. F. Armstrong, in the preparation of monographs on the glycosides and the carbohydrates, and $\mathrm{Mr}$. Howard was a research worker at the Fuel Research Station, Greenwich.

WE regret to announce the following deaths :

Capt. J. E. Bernier, known for his explorations of the Canadian Arctic, on December 27, aged eightytwo years.

Sir Maurice Craig, consulting physician in psychological medicine to Guy's Hospital, on January 6, aged sixty-eight years.

Prof. Roland B. Dixon, professor of anthropology in Harvard University since 1916, an authority on the languages and culture of the Indians of the Pacific coast, on December 20, aged fifty-nine years.

Sir Alfred Ewing, K.C.B., F.R.S., formerly professor of mechanism and applied mechanics in the University of Cambridge, lately principal and vicechancellor of the University of Edinburgh, on January 7, aged seventy-nine years.

Mr. J. C. Lawson, University lecturer in classics in the University of Cambridge, an authority on Greek folk-lore, on January 5, aged sixty years. 